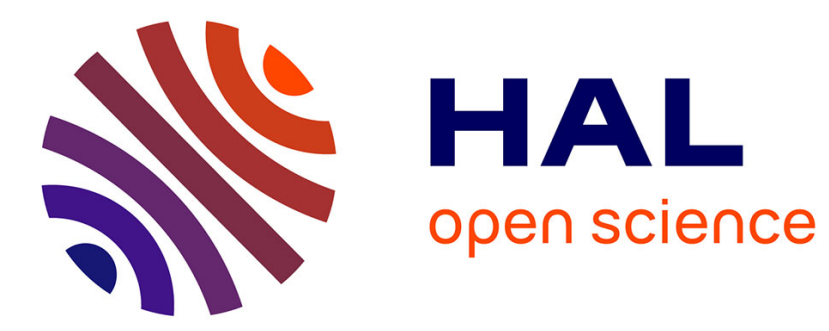

\title{
Research ethics, publication ethics and the dialectics of scientists trying not to behave badly: a comment on the advantages and limitations of Twin Assessment of Clinical Trials (TACT)
}

Heiner Fangerau

\section{To cite this version:}

Heiner Fangerau. Research ethics, publication ethics and the dialectics of scientists trying not to behave badly: a comment on the advantages and limitations of Twin Assessment of Clinical Trials (TACT). Journal of Public Health, 2009, 17 (6), pp.433-434. 10.1007/s10389-009-0284-3 . hal00535292

\section{HAL Id: hal-00535292 \\ https://hal.science/hal-00535292}

Submitted on 11 Nov 2010

HAL is a multi-disciplinary open access archive for the deposit and dissemination of scientific research documents, whether they are published or not. The documents may come from teaching and research institutions in France or abroad, or from public or private research centers.
L'archive ouverte pluridisciplinaire HAL, est destinée au dépôt et à la diffusion de documents scientifiques de niveau recherche, publiés ou non, émanant des établissements d'enseignement et de recherche français ou étrangers, des laboratoires publics ou privés. 


\title{
Research ethics, publication ethics and the dialectics of scientists trying not to behave badly: a comment on the advantages and limitations of Twin Assessment of Clinical Trials (TACT)
}

\author{
Heiner Fangerau
}

Received: 15 April 2009 / Accepted: 27 July 2009 /Published online: 20 August 2009

(C) Springer-Verlag 2009

\begin{abstract}
Aim This comment addresses conflicts of interest in the publication of research results.

Subject and Methods Based on the concept of values in science, the problem of scientific misconduct related to publishing research results is treated hermeneutically. Franz Porzsolt's approach to assessing studies and the implications for solving conflicts of interest are evaluated.

Results It is argued that conflicts of interest reflect the difficulty of balancing values in science and that science would become arbitrary and worthless for sponsors of research if it lacked its traditional values.

Conclusion Keeping scientific values and coping with conflicts of interest are essential for the future credibility and accountability of scientific endeavors. The communitarian approach to Twin Assessment of Clinical Studies might answer both demands.
\end{abstract}

Keywords Values · Publication ethics . Conflict of interest

"Scientists behaving badly" was the title of a study on scientific misconduct published in Nature in 2005. More than 3,200 researchers answered the question whether they had had to report any personal scientific misconduct or unethical behavior regarding their work during the last 3 years. The result was astonishing since a great majority rather openly admitted to having betrayed, deceived or

H. Fangerau $(\bowtie)$

Institute of the History, Philosophy and Ethics of Medicine,

Ulm University,

Frauensteige 6,

89075 Ulm, Germany

e-mail: heiner.fangerau@uni-ulm.de engaged in another behavior considered as inappropriate in research. Furthermore, the study showed both a general awareness of the fact that certain ethical norms exist in research and an awareness that these norms are not always followed. Listed among the top ten behaviors were "not properly disclosing involvement in firms whose products are based on one's own research," "failing to present data that contradict one's own previous research", and "changing the design, methodology or result of a study in response to pressure from a funding source" (Martinson et al. 2005). The sample of these misconducts reflects the difficult position of scientists between institutional academic values and personal interests that might either be internally motivated (for example, by ambition) or externally fostered (for example, by sponsors).

Robert Merton once determined a group of central institutional ethical norms that constituted a basic value set in science. These norms included an organized skepticism, disinterestedness - including academic freedom unbiased by authorities, universalism and finally the open communication of research results labeled as "communism" (Merton (1942) 1973). In face of the dictum that 'science goes where the money is,' these values seem to be anachronistic, and it might be asked whether alternative norms do not capture the reality of science much better. Would it not be clever for a scientist to promote the norms of capitalism, particularism and interestedness as key elements during the daily struggle for reputation, funding and research grants? Indeed, a recent (pilot)study by Macfarlane and Cheng suggests that especially disinterestedness as a scientific norm loses support. Aligning research with funding opportunities has become common - with female researchers more likely to act in such a pragmatic way than male (Macfarlane and Cheng 2008). In addition, previous studies 
have shown that this stance also results in a publication bias: sponsorship of research by industries was statistically significantly correlated with pro-industry conclusions (Bekelman et al. 2003).

However - and this is the crucial point - industry can only benefit from pro-industry conclusions made by scientists if consumers, stakeholders, other scientists, and finally industrial representatives themselves believe in the scientific values of universalism, communism, disinterestedness and scepticism. Otherwise, pro-industry conclusions were arbitrary and worthless or "valueless," respectively. Values are the capital of science. Thus, scientists and their sponsors work and act within a stress field of values. This stress field is a font of conflicts of interest, the most prominent of which relate to the role of the scientist as a disinterested searcher for universal scientific facts and his dependence on sponsors. The sponsors might be inclined to have facts dressed, tuned and selected, because their economic profit is closely connected to scientific opinion framing. In order to back traditional values in science, many medical journals have implemented conflict of interest disclosure policies with limited success. It has to be kept in mind that not only researchers, but also journal editors and owners have an interest in cooperation with sponsors (Lexchin and Light 2006).

Franz Porzsolt's study on "Advantages and Limitations of Twin Assessment of Clinical Trials" addresses exactly this stress field resulting from competing values. He offers a tool to foster peer assessment on a collaborative communitarian level that intends to overcome individual conflicts of interest. Nevertheless, his study and his experience in conducting the study show how difficult it is for the individual scientists to balance the good means of peer assessment with maybe an end (outcome) that is against one's own interests. In his study Porzsolt mentions an industry-based and a university-based referee who assessed the analyzed papers initially. The industry-based referee, however, abstained from being listed among the authors of the study, because the outcome of the assessment contradicted his genuine interest to work in favor of his employer (Porzsolt, personal communication). This is not only a legitimate but also a wise behavior, and the fact that Porzsolt's study is now published despite one referee's retreat shows that the communitarian approach of twin assessment is a useful attempt at fostering traditional values in science. Keeping scientific values and coping with conflicts of interest are essential for the future credibility and accountability of scientific endeavors. Thus, the awareness of a conflict of interest and coping with it without being relativistic are generally a good sign. It shows that scientific values prevail and that they prevent science from becoming arbitrary or being reduced to absurdity.

Conflict of Interest The author confirms that there are no relevant associations that might pose a conflict of interest.

\section{References}

Bekelman JE, Li Y, Gross CP (2003) Scope and impact of financial conflicts of interest in biomedical research: a systematic review. JAMA 289:454-465

Lexchin J, Light DW (2006) Commercial influence and the content of medical journals. BMJ 332:1444-1447

Macfarlane B, Cheng M (2008) Communism, universalism and disinterestedness: re-examining contemporary support among academics for Merton's scientific norms. J Acad Ethics 6:67-78

Martinson BC, Anderson MS, de Vries R (2005) Scientists behaving badly. Nature 435:737-738

Merton RK (1973) [1942]) The normative structure of science. In: Merton RK, Storer NW (eds) The sociology of science: theoretical and empirical investigations. University of Chicago Press, Chicago, pp 267-278 